\title{
Pelatihan Penggunaan Learning Management System Berbasis SPADA bagi Dosen Program Studi PG-PAUD
}

\author{
Dema Yulianto1, *Hanggara Budi Utomo², Rosa Imani Khan ${ }^{3}$, Ridwan ${ }^{4}$ \\ 1,2,3,4 Universitas Nusantara PGRI Kediri, Kediri, Indonesia
}

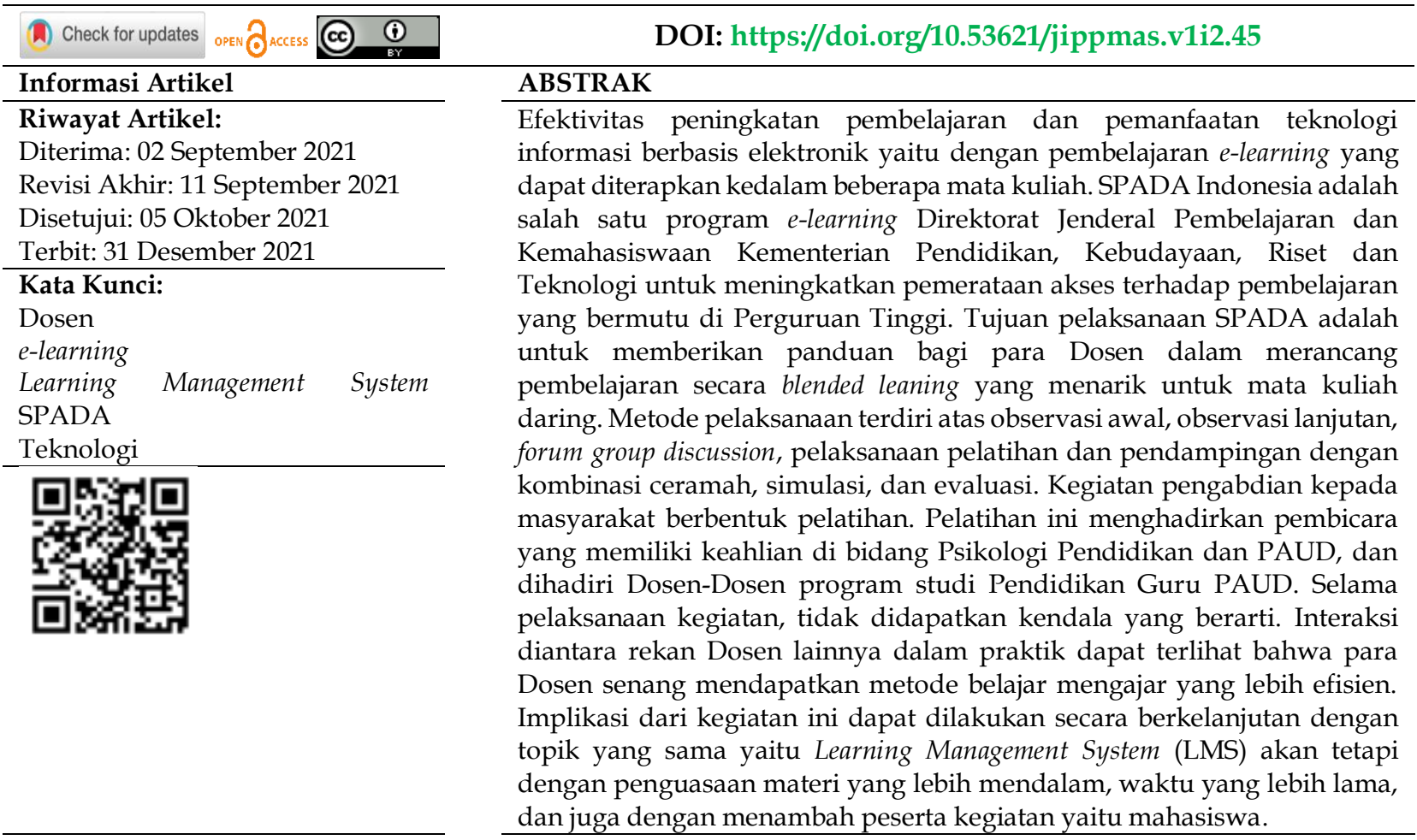

\section{PENDAHULUAN}

Merebaknya wabah covid-19 yang tentunya tiada berakhir memiliki dampak positif dalam mendukung pendidikan era industri 4.0. Pendidik dan peserta didik diharapkan mampu membawa perubahan positif dalam mengembangkan kreatifitas serta inovasi pembelajaran melalui kolaborasi tugas bersama dengan memanfaatkan dan mengimplementasikan teknologi informasi. Implementasi teknologi informasi dalam pendidikan dapat diterapkan dengan sistem pembelajaran dalam jaringan atau dikenal dengan istilah pembelajaran daring. Pembelajaran yang dilaksanakan secara daring di tengah pandemic covid-19 lambat laun menunjukkan perkembangan yang semakin meningkat sehingga hal ini memberikan tingkat efektivitas kualitas belajar siswa, dan siswa tidak punya pilihan lain untuk tetap belajar secara daring (Saputra et al., 2021; Tauhid et al., 2020). Hal ini juga terjadi di perguruan tinggi dimana mahasiswa harus terbiasa dengan aplikasi teknologi yang digunakan selama pembelajaran daring yang dapat meningkatkan dukungan psikologis selama pembelajaran daring (Ratnawati et al., 2021).

Cara yang efektif dalam peningkatan pembelajaran daring dan memanfaatkan teknologi informasi berbasis elektronik yaitu dengan penerapan e-learning, yang dapat diterapkan kedalam beberapa mata kuliah. Manfaat yang diperoleh dengan adanya sistem e-learning adalah adanya pertukaran pendapat, ide dan ilmu pengetahuan antar perguruan tinggi maupun masyarakat yang secara berkelanjutan memberikan implikasi 
pada perkembangan budaya, sosial dan ekonomi masyarakat Indonesia secara menyeluruh. Ketika mahasiswa memanfaatkan e-learning selama belajar, maka tentunya akan memiliki dampak baik bagi mahasiswa untuk memperluas wawasan yang semakin modern, serta sistem e-learning initidak sebatas hanya pengajaran di dalam ruangan, namun ada interaksi pembelajaran jarak jauh (Wahyuni \& Sadiah, 2020). Berbagai penelitian menunjukkan dampak yang ditimbulkan oleh penerapan teknologi informasi dan komunikasi yang cukup mendukung dalam e-learning (Kaware \& Sain, 2015; Nuris et al., 2018; Ardini et al., 2020; Setiadi et al., 2016; Brun \& Hinostroza, 2014). Adanya pemanfaatan e-learning, seperti halnya penggunaan moodle dan LMS dapat mengoptimalkan pembelajaran online dan mampu mengatasi keterbatasan ruang, serta secara khusus sebagai solusi media pembelajaran berbasis TIK pada masa pandemic covid19 bagi tenaga pendidik (Ilmadi et al., 2020; Widadi \& Safitri, 2021). E-learning menjadi suatu bentuk inovasi pendidikan untuk menjawab keresahan masyarakat akan ketersediaan sumber belajar berbasis TIK di tengah pandemic covid-19 (Astini, 2020).

Peran dan usaha dari Pemerintah yang diprakarsai oleh Kementerian Pendidikan, Kebudayaan, Riset dan Teknologi adalah mendorong sistem pendidikan yang adaptif melalui inovasi pemerataan pelaksanaan pembelajaran daring. Salah satu program Direktorat Jenderal Pembelajaran dan Kemahasiswaan Kementerian Pendidikan, Kebudayaan, Riset dan Teknologi yang bermutu di Perguruan Tinggi adalah sistem pembelajaran daring (SPADA) Indonesia. Tersedianya sistem pembelajaran daring melalui SPADA Indonesia memberikan kesempatan mahasiswa dari satu perguruan tinggi tertentu untuk dapat mengikuti suatu mata kuliah berkualitas tertentu dari perguruan tinggi lain dan hasil belajarnya dapat direkognisi oleh perguruan tinggi dimana mahasiswa tersebut terdaftar (Spada, 2015). Nilai yang diperoleh melalui pembelajaran blended dengan perguruan tinggi lain (credit learning) dapat dialihkan (credit transfer) dengan nilai sama di perguruan tinggi dimana ia terdaftar sebagai mahasiswa. Hal ini sejalan dengan tuntutan Pendidikan era industri 4.0 dan society 5.0 bahwa teknologi merupakan aspek penting dalam kehidupan, tidak terkecuali dunia pendidikan tinggi (Andriyanto et al., 2020).

Sekilas tentang sistem pembelajaran daring (SPADA) Indonesia diresmikan oleh Wakil Presiden Republik Indonesia pada tanggal 15 Oktober 2014. Sebanyak 51 perguruan tinggi baik negeri maupun swasta pada tahun 2017 telah bergabung menggunakan SPADA. Perguruan tinggi harus bisa meningkatkan akses, relevansi, dan kualitas pendidikan tinggi untuk menghasilkan tenaga profesional yang terampil (Wahyuni \& Sadiah, 2020). Keberadaan teknologi informasi dan komunikasi (TIK) yang semakin up-to-date, menawarkan potensi besar untuk menjawab tantangan atas pembelajaran daring dan memberikan peluang dilakukannya pendidikan tinggi berjejaring (networked higher education) dan pembelajaran daring (Spada, 2015).

Perkembangan teknologi yang begitu cepat dan masif membuat inovasi pembelajaran wajib dilakukan melalui daring. Hadirnya inovasi SPADA mampu membuat kolaborasi yang baik antara pendidik dan peserta didik dengan menggunakan sumber belajar yang bervariasi berbasis teknologi informasi dan sarana media lain. Selaras dengan visi prodi Pendidikan Guru PAUD UNP Kediri yaitu menjadi program studi dengan reputasi nasional dalam pengembangan ilmu pengetahuan, teknologi dan seni di bidang Tri Dharma Perguruan Tinggi pendidikan anak usia dini untuk menghasilkan sumber daya manusia yang unggul dan inovatif pada tahun 2026, dan mendukung visi menyelenggarakan pendidikan akademik dan profesi yang menghasilkan pendidik, pengelola lembaga, dan instruktur pendidikan anak usia dini yang unggul dan inovatif 
melalui optimalisasi penggunaan teknologi informasi dan komunikasi, maka perlu adanya pelatihan yang berimplikasi pada pengembangan inovasi dan peningkatan kualitas pembelajaran pada mata kuliah.

Tujuan pelatihan Learning Management System (LMS) SPADA Bagi Dosen Program Studi PG-PAUD di Universitas Nusantara PGRI Kediri sebagai dukungan salah satu program Kementerian Pendidikan, Kebudayaan, Riset dan Teknologi yang perlu diketahui dan dilaksanakan, sehingga dapat meningkatkan kompetensi akan pentingnya kualitas pembelajaran dengan pemanfaatan media teknologi informasi yang nantinya akan dirasakan jangka panjang dampak positifnya.

\section{PERMASALAHAN}

Berdasarkan analisis permasalahan yang ada, maka tim abdimas menyusun rumusan masalah dalam kegiatan pengabdian ini, antara lain:

1. Bagaimana Dosen program studi PG-PAUD UNP Kediri dapat mengenali $e$-learning LMS SPADA UNP Kediri?

2. Bagaimana Dosen program studi PG-PAUD UNP Kediri dapat menyusun aktivitas pembelajaran berbasis e-learning yang terintegrasi dengan Learning Management System (LMS) SPADA UNP Kediri?

\section{METODE PELAKSANAAN}

Metode pelaksanaan selama kegiatan Pengabdian Kepada Masyarakat, antara lain: (1) observasi awal dengan kegiatan mencari informasi data proses pembelajaran dosen PGPAUD ditengah pandemic covid-19. Setelah itu, tim pengabdi melakukan konsultasi dan perijinan dengan Dekan FKIP, Ketua LPPM, dan tim SPADA UNP Kediri untuk mensosialisasikan LMS SPADA UNP Kediri pada dosen PG-PAUD; (2) observasi lanjutan. Setelah mendapat ijin, tim pengabdi selanjutkan melakukan observasi lanjutan untuk memperoleh data tentang kompetensi Dosen dalam penguasaan teknologi informasi dan sarana prasarana untuk kegiatan pelatihan; (3) tim pengabdi melakukan forum group discussion tentang permasalahan yang dihadapi Dosen dengan Ketua Program Studi PG-PAUD terkait dengan bagaimana meningkatkan kualitas pembelajaran secara blended learning dengan menggunakan platform Learning Management System SPADA Universitas Nusantara PGRI Kediri; (4) kegiatan pelatihan dan pendampingan dikemas secara luring dan daring dengan mode asinkronus. Metode kombinasi juga diterapkan pada kegiatan pengabdian ini antara lain metode ceramah, tanya jawab, simulasi, dan evaluasi. Khalayak sasaran pada kegiatan ini adalah Dosen program studi PG-PAUD sebanyak 10 peserta. Berikut alur pelaksanaan pengabdian seperti terlihat pada gambar di bawah ini. 

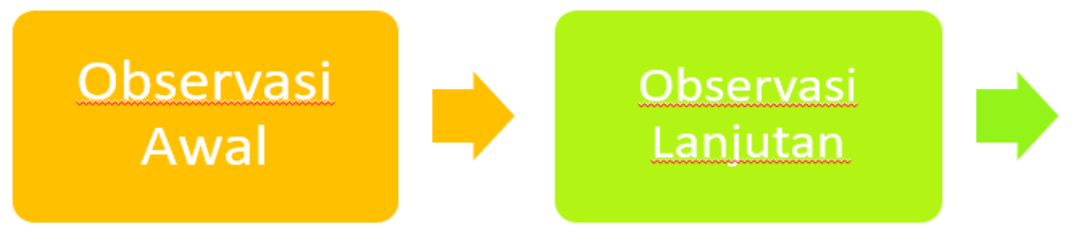

Forum Group

Disccussion
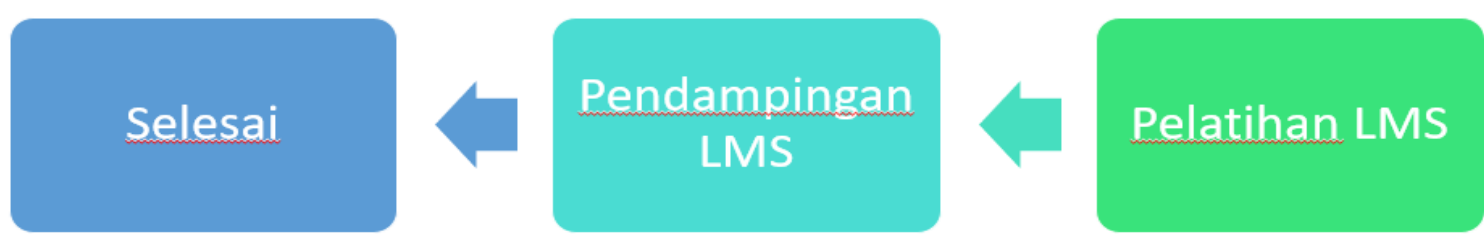

Gambar 1. Alur tahap pelakasanaan pengabdian

\section{PELAKSANAAN}

Pelaksanaan kegiatan pengabdian kepada masyarakat tentang Pelatihan Penggunaan Learning Management System (LMS) secara Daring bagi Dosen Program Studi PG-PAUD di Universitas Nusantara PGRI Kediri dilakukan pada tanggal 4 Agustus 2021 selama kurang lebih 3 jam. Adapun rincian kegiatan secara keseluruhan dapat dijelaskan pada tabel di bawah ini.

Tabel 1. Jadwal kegiatan pengabdian masyarakat

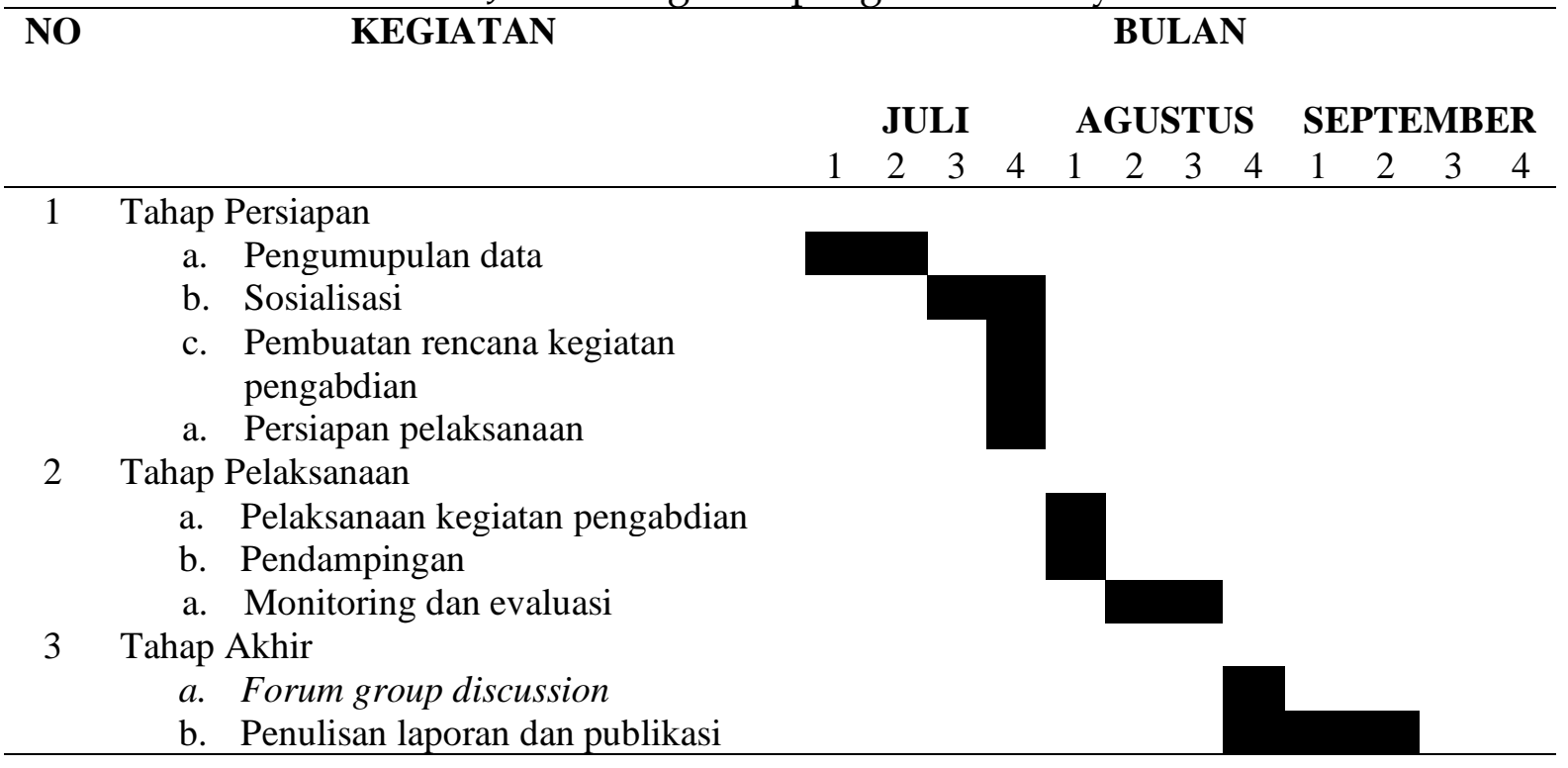

Solusi dan target luaran dalam kegiatan Pengabdian Kepada Masyarakat, adalah sebagai berikut: (1) penggunaan Learning Management System (LMS) SPADA Bagi Dosen Program Studi PG-PAUD di Universitas Nusantara PGRI Kediri sebagai dukungan salah satu program Kementerian Pendidikan, Kebudayaan, Riset dan Teknologi yang perlu diketahui dan dilaksanakan, sehingga dapat meningkatkan kompetensi akan pentingnya kualitas pembelajaran dengan pemanfaatan media teknologi informasi yang nantinya akan dirasakan jangka panjang dampak positifnya; (2) secara umum luaran dari kegiatan pengabdian ini adalah Dosen dapat menyusun aktivitas pembelajaran asinkron yang relevan untuk mencapai capaian pembelajaran yang telah ditentukan melalui platform Learning Management System SPADA Universitas Nusantara PGRI Kediri. Luaran berikutnya adalah laporan hasil pengabdian kepada masyarakat yang dilaksanakan oleh 
tim pengabdi, yang kemudian disusun menjadi sebuah artikel ilmiah, dan di terbitkan pada jurnal pengabdian kepada masyarakat.

\section{HASIL DAN DISKUSI}

Moderator acara sosialisasi ini adalah mahasiswa tingkat satu yang bernama Husna Istifadah. Sesi pertama pemaparan materi dengan judul standar pelaksanaan SPADA UNP Kediri selama 15 menit disampaikan oleh Dr. Dema Yulianto, M.Psi. Adanya informasi tentang standar pelaksanaan sistem pembelajaran daring dapat berdampak positif bagi para pendidik yaitu Dosen, dimana mereka bisa lebih mudah dalam melaksanakan pembelajaran secara efektif dan efisien. Sesi kedua pemaparan materi tentang standar pengelolaan SPADA UNP Kediri disampaikan oleh Rosa Imani Khan., M.Psi selama 15 menit. Sesi ketiga penyajian materi tentang simulasi pengenalan fitur LMS SPADA UNP Kediri melalui tautan vclass.unpkediri.ac.id, dengan metode kombinasi diskusi dan praktek disampaikan oleh Dr. Hanggara Budi Utomo, M.Pd., M.Psi serta didampingi oleh Ridwan, S.Ag, M.Pd. Materi pengembangan dan sekaligus mempraktikkan ini memang sangat dibutuhkan oleh Dosen pengguna SPADA yang dapat dipraktikkan secara mandiri dengan aplikasi vclass.unpkediri.ac.id.

Materi simulasi yang disampaikan terdiri atas 3 (tiga) bagian, yaitu: pengenalan konfigurasi kelas, manajemen materi, dan manajemen aktivitas. Fitur yang terdapat dalam bagian konfigurasi kelas, antara lain:

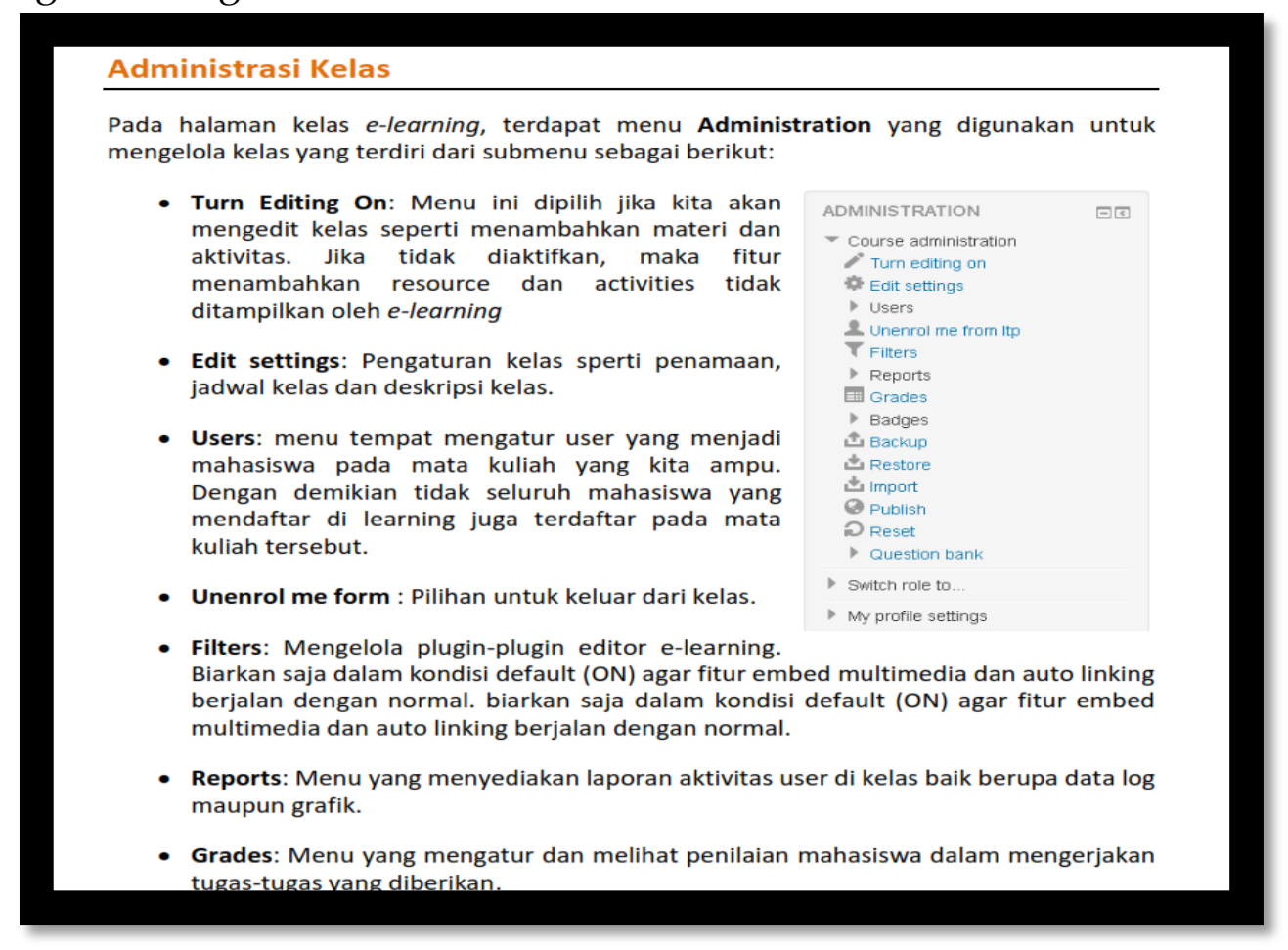


- Badges: Menu yang mengatur peringkat peserta perkuliahan. Nilai yang diberikan oleh dosen secara otomatis akan diakumulasikan oleh sistem permahasiswa dan diperingkatkan. Di menu ini kita juga dapat menentukan sendiri skala peringkat dan standar kelulusan untuk mata kuliah kita.

- Backup: Digunakan untuk membackup seluruh konfigurasi, aktivitas, dan file yang ada dalam kelas ke komputer lokal. Hal ini dilakukan untuk mengantisipasi jika sewaktuwaktu server mengalami masalah

- Restore: Mengembalikan data hasil backup dari komputer lokal ke e-learning

- Import: Memasukkan data dari kelas lain yang kita miliki. Misalnya kita telah membuat kelas sosiologi pendidikan di semester ganjil tahun lalu dan kembali akan mengelolanya untuk tahun ini. Akan sangat merepotkan jika kita harus memasukkan bahan ajar dan tugas kembali satu-persatu. Dengan menggunakan fitur ini, kita tinggal mengimport data dari mata kuliah tahun lalu

- Reset: Digunakan untuk penghapusan data. Hal ini dilakukan jika kelas yang dulu telah digunakan dan akan digunakan lagi. Melalui menu reset ini, kita dapat malakukan penghapusan log, daftar mahasiswa di kelas, aktivitas mahasiswa, dan penilaian.

- Swith role to: Berfungsi untuk melihat tampilan elearning dari sisi non-editing teacher (asisten dosen) atau dari sisi mahasiswa.

- My profile settings: Mengatur profile seperti deskripsi diri, penggantian password dan input foto profil

Gambar 2. Fitur Konfigurasi kelas

(Sumber: Sumarno et al., 2019)

Selanjutnya, bagian kedua adalah manajemen materi, dimana Dosen dapat membuat materi baru di kelas yang telah Dosen kelola. Dosen terlebih dahulu harus menekan tombol menu turn editing on yang ada di sebelah kanan atas.

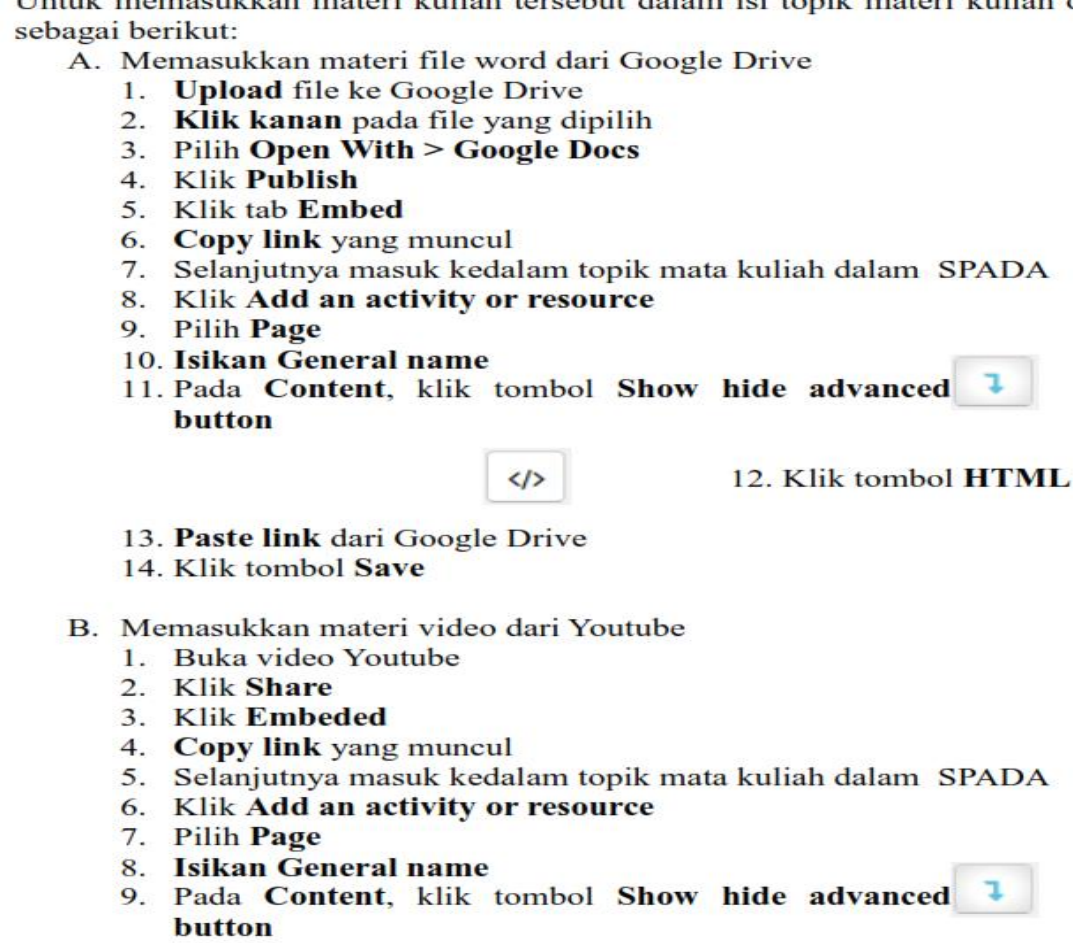

A. Memasukkan materi file word dari Google Drive

1. Upload file ke Google Drive

2. Klik kanan pada file yang dipilih

3. Pilih Open With > Google Docs

4. Klik Publish

5. Klik tab Embed

6. Copy link yang muncul

7. Selanjutnya masuk kedalam topik mata kuliah dalam SPADA

8. Klik Add an activity or resource

9. Pilih Page

10. Isikan General name

11. Pada Content, klik tombol Show hide advanced 7 button

13. Paste link dari Google Drive

14. Klik tombol Save

B. Memasukkan materi video dari Youtube

1. Buka video Youtube

2. Klik Share

3. Klik Embeded

4. Copy link yang muncul

5. Selanjutnya masuk kedalam topik mata kuliah dalam SPADA

6. Klik Add an activity or resource

7. Pilih Page

8. Isikan General name

9. Pada Content, klik tombol Show hide advanced button

</> 10. Klik tombol HTML

Gambar 3. Fitur Manajemen Materi

(Sumber: Andriyanto et al., 2020) 
Fitur manajemen materi terdiri atas: book, file folder, lms content package, label, page, URL, dimana setiap fitur memiliki fungsi dan peran masing-masing. Adanya fitur dalam $e-$ learning telah menyediakan berbagai macam pilihan aktivitas yang dapat dipilih oleh Dosen berkaitan dengan pemberian penugasan secara online, diantaranya adalah: assignments, chatting, forum, quis (Sumarno et al., 2019).

Penyelenggaran SPADA menggunakan sarana Learning Management System (LMS) yang ditentukan oleh Universitas. Akun pengguna LMS Universitas, yaitu Dosen dan Mahasiswa, dikelola oleh Layanan Laboratorium Terpadu (LLT). Persyaratan minimal yang harus dilengkapi adalah: (a) program mapping (RPS sesuai karakteristik SPADA), materi ajar/handout untuk 14 kali pertemuan, topic introduction (html) disesuaikan dengan jumlah penyampaian bahan ajar daring; (b) penjelasan bahan ajar untuk pertemuan daring dengan rincian sebagai berikut: video pembelajaran, e-modul; (c) tugas online minimum 2 kali, quiz online minimum 2 kali, dan forum diskusi online disesuaikan dengan jumlah penyampaian materi online; (d) UTS dan UAS tetap dilaksanakan di kelas seperti metode konvensional/reguler (Andriyanto et al., 2020).

Produk yang dihasilkan dari pelatihan LMS SPADA ini terkait dengan bagaimana pendidik dalam hal ini merupakan Dosen, berperan serta dalam menyelenggarakan perkuliahan daring. Peran serta Dosen dalam aktivitas SPADA ini adalah sebagai: (a) perancang pembelajaran; (b) penyusun dan/atau pengembang bahan ajar dan media; (c) produser bahan ajar dan media; (d) penulis soal, tugas, dan/atau evaluasi hasil belajar; (e) pengampu dan pengelola mata kuliah; (f) tutor pada proses pembelajaran; (g) pembimbing praktik dan/atau tugas akhir; dan/atau (h) penguji (Andriyanto et al., 2020) Adanya kegiatan ini dirasa sangat penting guna pemenuhan tanggung jawab Dosen dalam proses belajar mengajar khususnya pemenuhan pelaksanaan Tridharma Perguruan Tinggi, dan sebagai tanggung jawab Dosen dalam mensukseskan program Pemerintah dengan memanfaatkan aplikasi e-learning selama pandemic covid-19 (Wahyuni \& Sadiah, 2020).

Kegiatan forum group discussion dilaksanakan secara asinkronus untuk merancang fitur pembelajaran di tautan vclass.unpkediri.ac.id, yang selanjutnya pemateri akan mengecek secara berkala tampilan di LMS masing-masing Dosen. Apabila mengalami kendala dalam perancangan di LMS, para peserta yang notabene Dosen Prodi PG-PAUD dapat melakukan komunikasi dengan menanyakan hal yang dirasa sulit kepada pemateri. Pelaksanaan monitoring dilaksanakan untuk mengetahui apakah dalam memanfaatkan LMS SPADA UNP Kediri berbasis teknologi informasi tersebut ada kendala atau tidak. Berikut dokumentasi sosialisasi pendampingan penggunaan Learning Management System (LMS) secara Daring bagi Dosen Program Studi PG-PAUD di Universitas Nusantara PGRI Kediri.

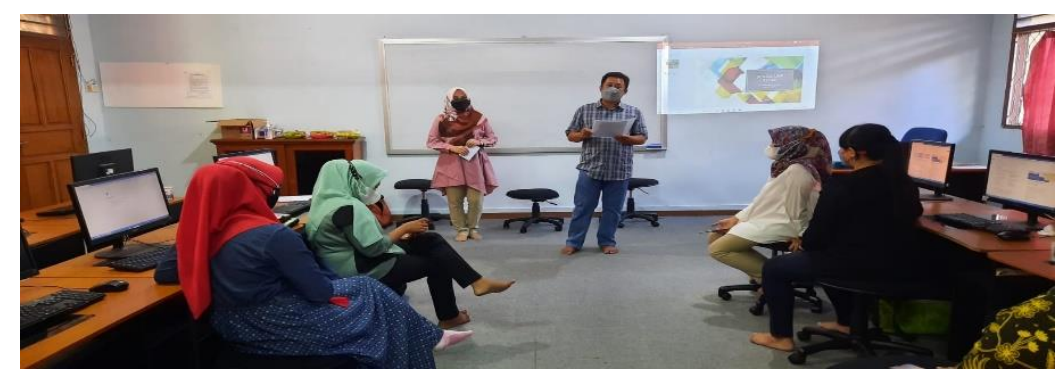

Gambar 4. Pemateri memberikan materi sosialisasi tentang standar pelaksanaan SPADA UNP Kediri 


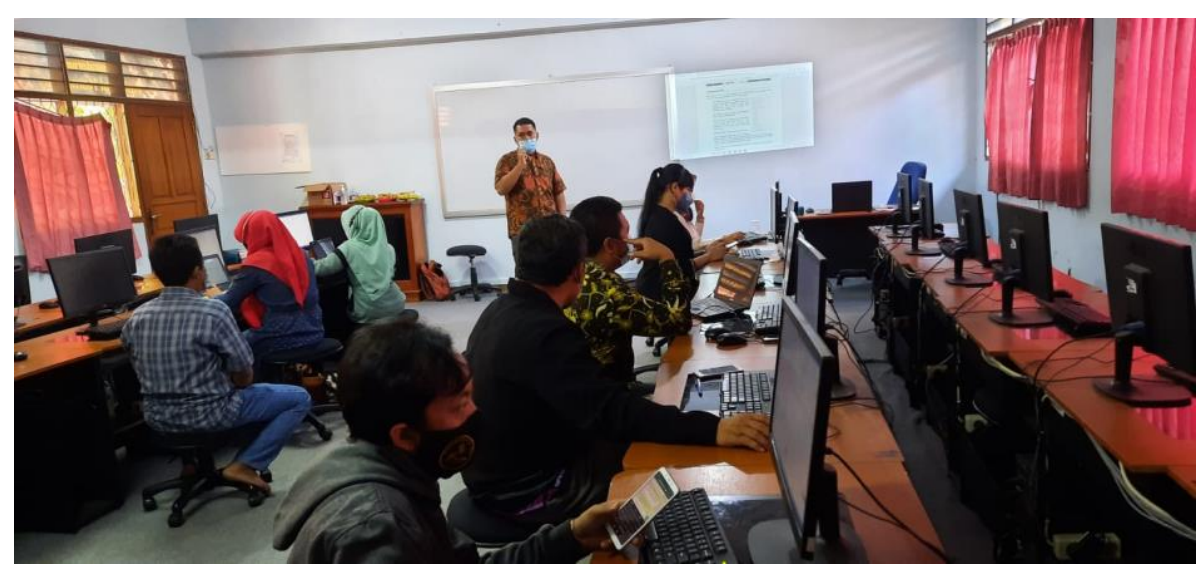

Gambar 5. Pemateri memberikan materi sekaligus simulasi pengenalan fitur LMS SPADA UNP Kediri melalui tautan vclass.unpkediri.ac.id

\section{KESIMPULAN}

Selama pelaksanaan kegiatan, Dosen Prodi PG-PAUD UNP Kediri dapat mengikuti kegiatan dengan baik dan sangat antusias dalam pemanfaatan secara gratis Learning Management System (LMS) SPADA UNP Kediri. Interaksi diantara rekan Dosen lainnya dalam praktik dapat terlihat bahwa para Dosen senang mendapatkan metode belajar mengajar yang lebih efisien. Namun demikian, ada sedikit kendala terkait keterbatasan jaringan internet di laboratorium komputer. Kendala tersebut pada akhirnya dapat teratasi dengan menghubungi petugas laboratorium komputer. Keterbatasan yang lain yaitu adanya kesulitan memahami istilah yang terdapat di LMS, namun demikian tim pengabdi dapat mengantisipasi dengan memberikan $e$-book panduan penggunaan LMS SPADA UNP Kediri untuk dipelajari lebih mendalam. Implikasi dari kegiatan pengabdian ini adalah mahasiswa juga perlu adanya edukasi cara-cara dalam penggunaan LMS agar mahasiswa menjadi lebih mudah menggunakan LMS sebagai bagian dari fasilitas sarana belajar mengajar secara daring. Selanjutnya, untuk pengabdian berikutnya, kegiatan ini dapat dilakukan secara berkelanjutan dengan topik yang sama yaitu Learning Management System (LMS) akan tetapi dengan materi yang lebih mendalam, waktu yang lebih lama, dan juga dengan menambah peserta kegiatan yaitu mahasiswa.

\section{UCAPAN TERIMA KASIH}

Kegiatan ini berjalan dengan baik berkat bantuan dan dorongan yang cukup luar biasa dari berbagai pihak, rasa hormat dan terima kasih kami sampaikan kepada: Tim SPADA Universitas Nusantara PGRI Kediri, Ketua LPPM dan Dekan Fakultas Keguruan dan Ilmu Pendidikan UNP Kediri, Kaprodi dan Dosen PG-PAUD UNP Kediri, dan yang lainnya yang tidak bisa disebutkan satu persatu, semoga menjadi amal ibadah disisi Tuhan Yang Maha Esa. Kegiatan pengabdian ini berlandaskan pada surat LPPM nomor: 091/LPPM-UN PGRI KD/VIII/2021.

\section{DAFTAR PUSTAKA}

Andriyanto, T., Nurfahrudianto, A., Aji, M. P. P., Aka, K. A., Ariyanto, R, D., \& Pristiani, Y. (2020). Panduan sistem pembelajaran daring Universitas Nusantara PGRI Kediri. Universitas Nusantara PGRI Kediri.

Ardini, L., Iswara, U. S., \& Retnani, E. D. (2020). The effectiveness of using e-learning as learning media during the covid pandemic 19. JKBM (Jurnal Konsep Bisnis Dan Manajemen), 7(1), 72-81. https:// doi.org/10.31289/JKBM.V7I1.4333 
Astini, N. K. S. (2020). Pemanfaatan teknologi informasi dalam pembelajaran tingkat sekolah dasar pada masa pandemi covid-19. Lampuhyang, 11(2), 13-25. https:/ / doi.org/10.47730/JURNALLAMPUHYANG.V11I2.194

Brun, M., \& Hinostroza, J. (2014). Learning to become a teacher in the 21st century: ICT integration in initial teacher education in Chile. Educational Technology E Society, 17(3), 222-238.

Ilmadi, I., Aden, A., Sastro, G., Rusdiana, Y., \& Isnurani, I. (2020). Pelatihan penggunaan moodle untuk mengoptimalkan pembelajaran secara online. Jurnal Abdidas, 1(6), 592-596. https:/ / doi.org/10.31004/ABDIDAS.V1I6.128

Kaware, S. S., \& Sain, S. K. (2015). ICT application in education: An overview. International Journal of Multidisciplinary Approach and Studies, 2, 25-32.

Nuris, D. M., Nuraini, U., \& Nagari, P. M. (2018). Blended learning application in the accounting education: Life-based learning paradigm. KnE Social Sciences, 3(3), 71. https://doi.org/10.18502/KSS.V3I3.1874

Ratnawati, V., Utomo, H. B., Setyaputri, N. Y., Ariyanto, R. D., \& Wulansari, W. (2021). Pengabdian masyarakat penerapan dukungan psikologis untuk meningkatkan perubahan positif pada mahasiswa selama pembelajaran daring. JURPIKAT (Jurnal $\begin{array}{llll}\text { Pengabdian Kepada } \quad \text { Masyarakat), } & \text { 66-76), }\end{array}$ https:/ / doi.org/10.37339/JURPIKAT.V2I1.481

Saputra, D. H., Ihsan, M. S., \& Atsani, L. G. M. Z. (2021). Penyuluhan literasi belajar online untuk masyarakat bersama komunitas pemuda mandiri. International Journal of Community Service Learning, 5(2), 169-174.

Setiadi, G., Joyoatmojo, S., Sajidan, S., \& Soeharto, S. (2016). The development of blended learning-based self-learning on classroom action research training material to improve teachers professionalism. In D. Rochsantiningsih (Ed.), Proceeding of the 2 nd International Conference on Teacher Training and Education (pp. 702-715). Universitas Sebelas Maret.

Spada, T. (2015). Spada Indonesia. https:/ / spada.kemdikbud.go.id/

Sumarno, A., Hartoto, H., Sopian, Y., Pramudyo, A., \& Ristadi, F. (2019). Panduan penggunaan e-learning LMS SPADA Indonesia. Dirjen Belmawa Kemenristekdikbud.

Tauhid, S. M., Foldra, F., \& Jayawinangun, R. (2020). Trend kajian pembelajaran daring: Suatu telaah pustaka. Jurnal Penelitian Sosial Ilmu Komunikasi, 4(2), 157-164.

Wahyuni, Y., \& Sadiah, H. T. (2020). Pelatihan dan pendampingan penggunaan elearning bagi Dosen-Dosen di Sekolah Vokasi Universitas Pakuan. Journal of Community Service Consortium, 1(2), 1-7.

Widadi, S., \& Safitri, M. (2021). Pelatihan aplikasi LMS moodle-cloud bagi guru SMP Muhammadiyah Semanu Kabupaten Gunungkidul. Jurnal Abdidas, 2(4), 848-858. https:/ / doi.org/10.31004/ABDIDAS.V2I4.352

\author{
Dr. Dema Yulianto, M.Psi \\ Universitas Nusantara PGRI Kediri, \\ Jl. KH. Achmad Dahlan 76, Kediri, East Java, 64112, Indonesia \\ Email: dema@unpkediri.ac.id
}

* Dr. Hanggara Budi Utomo, M.Pd., M.Psi (Corresponding Author)

Universitas Nusantara PGRI Kediri,

Jl. KH. Achmad Dahlan 76, Kediri, East Java, 64112, Indonesia

Email: hanggara@unpkediri.ac.id 
Rosa Imani Khan, M.Psi

Universitas Nusantara PGRI Kediri,

Jl. KH. Achmad Dahlan 76, Kediri, East Java, 64112, Indonesia

Email: rossa_rose@unpkediri.ac.id

\section{Ridwan, S.Ag., M.Pd}

Universitas Nusantara PGRI Kediri,

Jl. KH. Achmad Dahlan 76, Kediri, East Java, 64112, Indonesia

Email: ridwan@unpkediri.ac.id 